\title{
Introduction: the political economy of sustainable development
}

\section{BACKGROUND}

Sustainable development, defined as 'development that meets the needs of the present without compromising the ability of future generations to meet their own needs' is at the heart of global efforts to respond to the dual imperatives of environmental protection and economic development (UN 1987: 16). At the 1992 United Nations Conference on Environment and Development (UNCED, or the Rio de Janeiro 'Earth' Summit) sustainable development was formally adopted as the intergovernmental policy response to solving global environmental problems, embodied in the document Agenda 21 (UN 1993).

Sustainable development was an attempt to acknowledge the "limits to growth' first argued by the Club of Rome in 1972, while at the same time reconciling the need for economic development with environmental protection (Jacobs 2012: 4-5). This reconciling approach was taken one step further post-Rio, with the emergence of the 'triple bottom line' business philosophy, which linked the ideas of people, planet and profit, with society, the environment and the economy, and became a new form of business activity reporting, that took more than profit (single bottom line accounting) into consideration (Hindle 2008: 193-4). Perhaps the most serious competitor, 'green growth', emerged in the second half of the 2000s. This discourse appears to be more of an attempt to regain market and policy traction than a serious attempt to subvert the original intent of UNCED. Although it accepts the necessity of growth, it should perhaps be seen as a next generation effort to 'green up' the economy in the face of ongoing business-as-usual practices (Jacobs 2012: 5-6). Nevertheless, sustainable development remains at the heart of the UNCED legacy. How it is expressed, as the case studies in this book demonstrate, varies considerably over time, and context. The goals of sustainable development also remain somewhat elusive, both in terms of definition and implementation. 
The most relevant constituting agreements to arise out of Rio were the conventions on biological diversity (1992), climate change (1994), desertification (1996) and the non-legally binding Statement of Forest Principles (1992) (UN 1993). These have generated enabling policy instruments, including market-based mechanisms. After more than two decades, beyond the language of 'SusDev', specific sub-discourses have arisen within each initiative (in the case of the Forest Principles for example, sustainable forest management, or SFM). Policy commitments are implemented through a range of programmes, related governance arrangements and on-the-ground projects. The international community has also created other initiatives since the Earth Summit. The Millennium Development Goals (MDGs) aimed at tackling broader issues of poverty eradication, education, equality and health by the year 2015, included ensuring sustainable development (goal 7). Currently, a series of sustainable development goals (SDGs) are under negotiation, aimed at taking the sustainability-related aspects of the MDGs beyond 2015.

Responding to the issues identified at Rio and beyond poses considerable organisational challenges, and has created what has been referred to in recent years as a 'regime complex' (Victor and Keohane 2010). A wide range of institutions that share a number of commonalities coexist, but at times these can function within a series of 'silos' (Stiglitz 2003: 62-3). Discrete - even competitive - programmes have resulted in a considerable degree of 'static' across silos. In the case of climate change management, while the various initiatives under the UN Framework Convention on Climate Change (UNFCCC) are relatively well integrated, historically there has been a lack of coordination with the other Rio conventions. It has been suggested that the lack of effective interaction with other policy arenas - notably biological diversity - has led to 'trading off degradation of some ecosystems to achieve particular climate change adaptation and mitigation objectives' (Pittock 2013: 144). Governance scholars have called for more research into the institutional design and quality of the policy instruments in question (Zurn and Koenig-Archibugi 2006). This book is a response to this call, and investigates a number of major policy instruments and selected mechanisms (largely market-based) that have arisen in the wake of UNCED.

\section{CASE STUDIES}

In the wake of globalisation and the 'downsizing' of the public service as a consequence of neo-liberal political ideology, business and civil society, as well as government agencies, often implement sustainable development 
initiatives at the national level. Jurisdictions have increasingly shifted away from regulation solely under the control of government to methods of governance characterised by increased levels of non-state participation. This has resulted in a melange of public, private and civic service delivery, often based on 'soft' law approaches. These include voluntary standards and certification programmes, to be contrasted with traditional 'command/ control' regulatory models of state-based authority.

In the case of sustainable development, a range of types has been identified, including voluntary agreements, environmental management systems, 'eco-labels' and market-based instruments (Jordan et al. 2005). Agenda 21 referred specifically to 'economic and market-oriented approaches' (UN 1993: 70) in the context of climate change (Chapter 9, 'Protection of the atmosphere'), forest management (Chapter 11, 'Combatting deforestation') and biodiversity (Chapter 15, 'Conservation of biological diversity). This book focuses on these three central elements of Agenda 21 through a variety of case studies:

(1) Protection of the atmosphere: two approaches under UNFCCC aimed at reducing greenhouse gas emissions, the Clean Development Mechanism (CDM) - the fate of which is uncertain, as it was tied to the Kyoto Protocol (KP, which has now expired); and an emerging mechanism, anticipating the 2015 'post-Kyoto' climate negotiations, 'Reducing emissions from deforestation and forest degradation and the role of conservation, sustainable management of forests and enhancement of forest carbon stocks in developing countries' (REDD+);

(2) Combatting deforestation: Forest certification, exemplified by two rival schemes, the non-governmental organisation (NGO)-driven Forest Stewardship Council (FSC) and the industry-led Programme for the Endorsement of Forest Certification schemes (PEFC)-'ecolabelling' programmes for 'good' wood; and a European (EU) legality verification initiative to encourage timber-producing and processing countries to comply with EU-consuming countries' forestry regulations and procurement policies known as Forest Law Enforcement, Governance and Trade (FLEGT);

(3) Conservation of biological diversity: two financial incentives mechanisms originating within the UN Convention on Biological Diversity (CBD) to encourage the conservation of biological diversity, Payments for Ecosystem Services (PES) and biodiversity offset mechanisms (BOM). 
The 'sustainability complex' is used here to refer to the policy-related discourses, agreements, institutional arrangements, policy instruments, mechanisms and programmes of sustainable development. This complex is depicted in Figure 0.1 below.

\section{CENTRAL RESEARCH QUESTIONS AND PARAMETERS FOR ASSESSMENT}

In order to examine these initiatives, the book adopts a perspective informed by political economy. Here, a broad interpretation is used, to encompass the social, economic and environmental interests and issues that impact, both positively and negatively, on the case studies investigated. These interests are both state-based and territorial, such as national governments, and non-state and non-territorial, such as transnational corporations and civil society organisations. The issues surrounding sustainable development include geo-politics, money and governance. The intention of the book is to better understand the various types of policy instruments, mechanisms and specific programmes employed. It investigates the governance quality of the institutional arrangements employed to deliver the desired policy outcomes, and evaluates the nature of the interactions between the different interests involved in the case studies selected.

Against this backdrop, the book asks two main questions. First, what is right and wrong with the policy instruments for sustainable development? Second, what is the best model to advance sustainable development in the programmes identified? These questions are important, because they will assist stakeholders, the policy community and the general public to determine the governance capacity of market-based approaches to solve contemporary environmental, social and economic problems - and thereby contribute to sustainable development. 'Stakeholders' should be broadly understood, as the term relates to those who create, manage and implement such programmes, as well as those who may be either positively or negatively impacted by such programmes. Each of the programmes identified has its own unique strengths and weaknesses, and careful analysis of these endeavours, including participating stakeholders' perspectives, will assist in identifying the effectiveness of the mechanisms investigated. 


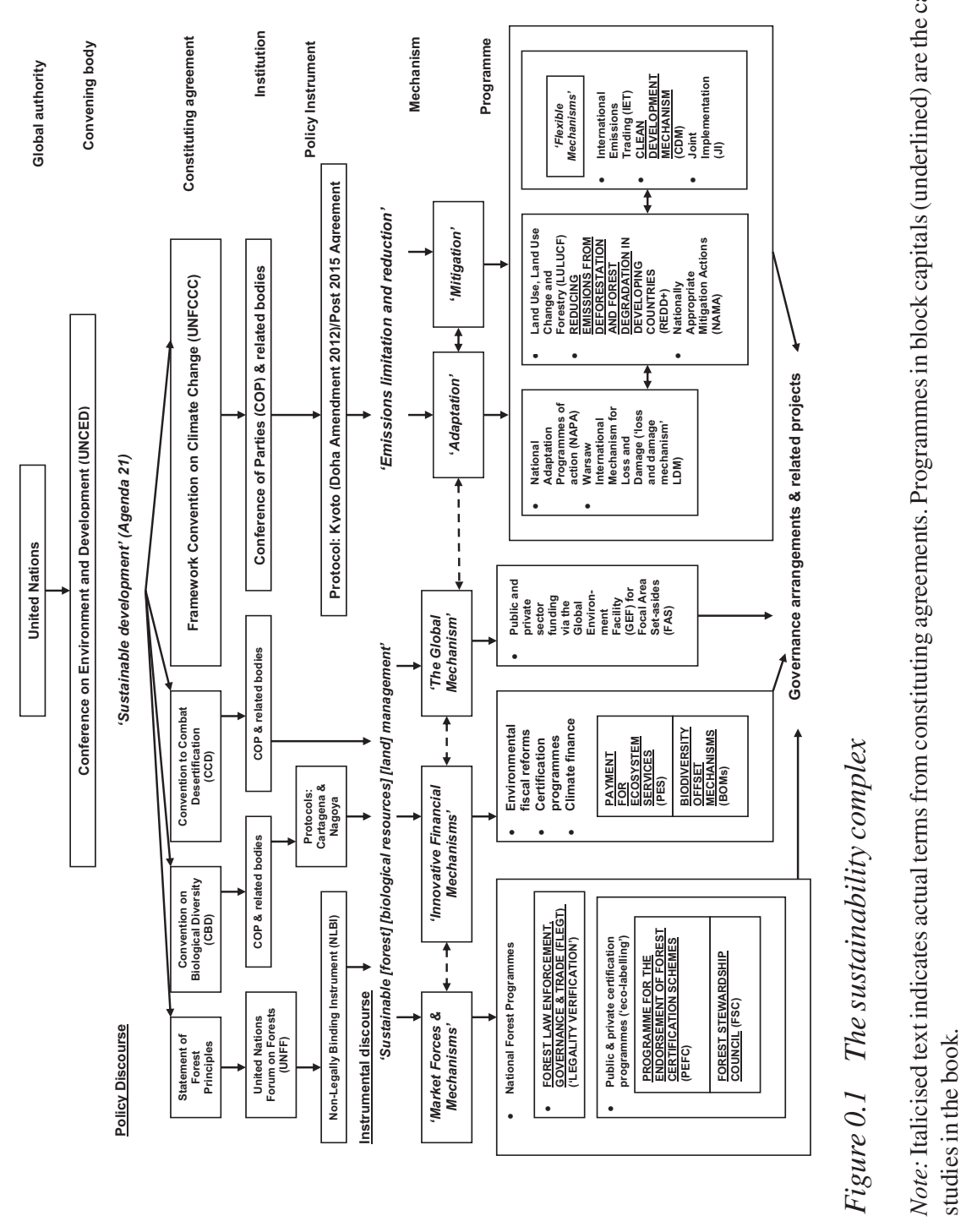


In response to the book's central questions, each of these initiatives is investigated using three parameters: the sources and means of delivery of finance; the 'North/South divide' and state and non-state actors; and the governance quality of sustainable development. Using the case studies, the book demonstrates how these parameters are crucial for the success or failure - of approaches for promoting human development and achieving environmental sustainability.

\section{Sources and Means of Delivery of Finance}

The availability and efficacy of internal and external means of financing are central to sustainable development. There are primarily two important sources and means of delivery of finance that can promote sustainable development: market-based instruments and external means at the international level.

Market-based instruments (e.g. economic instruments) can encourage behavioural change among consumers and polluters of environmental resources, while also raising revenue for environmental protection efforts (Panayotou 2013). There is also a degree of fiduciary investment, but the degree of engagement between policymakers and investors is limited (Haigh 2013: 111). At the state level, some sovereign wealth funds contribute, as is the case with Norway. A key internal source of finance is taxation, which can also play an important role in enhancing fiscal sustainability by redistributing the revenue to advance social, economic and environmental development outcomes (Sarker 2013: 85). This is particularly true for developed and advanced economies as they continuously try to broaden tax bases as a means of reducing budget deficits through promoting fiscal discipline. Alternatively, developing and least developed countries often suffer from a narrow tax base, and have limited ability to finance programmes and strategies that can promote sustainable development outcomes. In the case of resource-rich developing countries in particular, restoring fiscal sustainability means that such countries need to better utilise their natural resource endowments, and use the rents derived from the use of resources for social and economic development (Kazi and Sarker 2012). However, such countries often face the dilemma of a natural resource curse, and also suffer due to lower economic growth and welfare relative to resource-poor countries (Auty 2002). Resourcerich developing economies face challenges that could undermine their future development, including sustaining macroeconomic stability, a rapidly growing population and increased corruption (The World Bank 2011). For instance, many resource-rich developing countries in Africa, such as Angola and Nigeria, are experiencing regressive growth and 
significant poverty despite the vast resource rents available (Kazi and Sarker 2012). Selecting the right instruments to finance sustainable development outcomes remains a key challenge for developing countries as they often fail to meet the institutional and human resource requirements.

The second important source of finance is at the international level, where there are some external means to finance SDGs. These include country-specific foreign aid (such as overseas development assistance) and other forms of financial assistance (including soft loans via international financial institutions such as The World Bank, Asian Development Bank and the African Development Bank). The underlying principle driving overseas aid is that those who can do so have an obligation to help those who are in extreme need (Riddell 2007). This assumption is also maintained by a belief that the capacity-building provided actually helps those in need, and consequently creates a self-sustaining environment that can enhance sustainable development by meeting or fulfilling the MDGs (IMF 2015). Other examples of external funding include bilateral or country-specific assistance (e.g. the Indonesia-Australia Comprehensive Economic Partnership Agreement, IA-CEPA) and multilateral funding initiatives such as REDD+. A surge in external funding in all aspects of sustainable development (with the major focus on poverty and development) emerged after the United Nations World Summit on Sustainable Development (WSSD) in Johannesburg in 2002. Many UN organisations and donor agencies (partner countries) are contributing to finance projects that aim to enhance SDGs. The Global Environment Facility (GEF), for instance, has provided funds for more than 300 initiatives, with an emphasis on developing country forest management and conservation (Global Environment Facility 2010).

Focusing on improving the investment climate for sustainable development, and achieving long-term economic growth rather than short-term gains, will benefit future generations; that is, it will support intergenerational equity. The appropriate relationship between intergenerational equity, sources of finance, maintaining or enhancing capital, and sustainable development, is expressed in Figure 0.2.

However, in the aftermath of the global financial crisis in 2008, funding for sustainable development has been seen as a lower priority than restoring national economies. However, fiscal sustainability is a precondition to advancing social, economic and environmental development outcomes. The sources of funding for sustainable development, including private investment and sovereign wealth funds, as well as income taxation, need to be expanded, not contracted. Opportunities for 


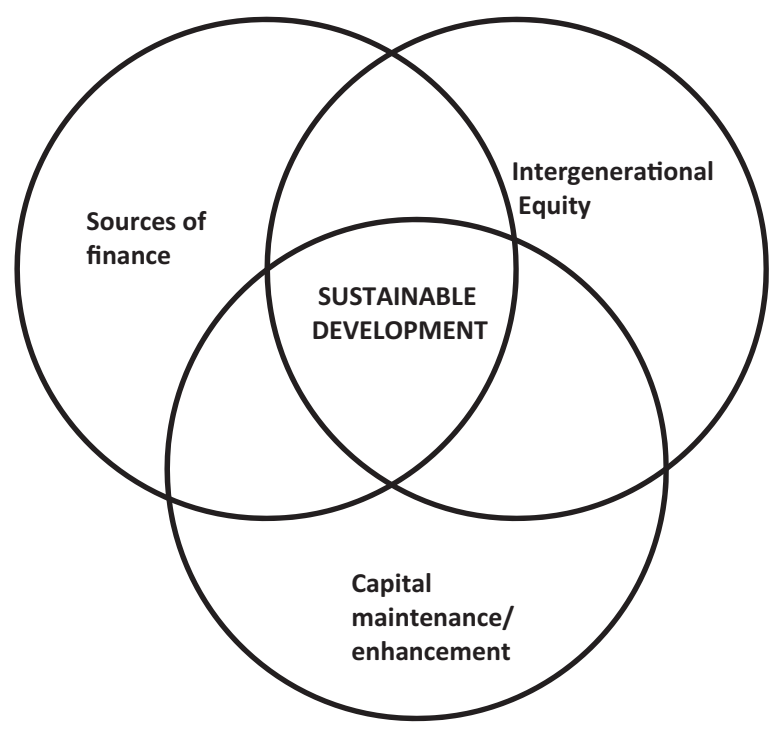

Figure 0.2 Financial system for sustainable development (Sarker 2013 adapted)

investment in sustainable development are currently hampered by inconsistencies, uncertainties and instabilities in the global regime's financial architecture (Haigh 2013). At present, the proportion of domestic taxes in developed countries going to overseas aid remains at a low level, and collection is often poorly enforced. Taxation systems should also maintain and develop rather than deplete capital for sustainability (Sarker 2013).

\section{North/South Relations and State/Non-State Actors}

Discussions at the Earth Summit over finance quickly led to conflict between developed and developing countries, and the creation of what have become entrenched geo-political groupings, lending popularity to the terms 'global North' and 'global South'.

The North, exemplified by the United States (US) and Europe, has historically been the developer of environmental technologies, and has been unwilling to share with, or transfer its products to, the South, expecting instead that these should be either purchased or simply delivered by Northern service delivery agencies and companies. The developing countries of the South, the largest grouping of which is collectively referred to as the ' $\mathrm{G} 77$ ', have fought strongly over the years 
to gain access to these technologies, while keeping control of the financial benefits arising from the exploitation of their own traditional and cultural knowledge. Towards the end of UNCED, a 'North/North' split arose between the US and the EU. The US opposed the idea of any kind of international regime to grant access to technology and benefitsharing, while the EU was prepared to provide financial assistance - so long as the intellectual property (IP) that went along with the technologies being shared was protected under World Trade Organization (WTO) rules on IP (Birnie 2000: 366-8).

The conference was not able to reach consensus on developing an 'Earth Charter', nor did any conventions on land-based pollution or deforestation eventuate. The South was of the view that developed countries intended to challenge their national sovereignty by placing a responsibility for dealing with the costs of the North's historical environmental pollution onto the South (Birnie 2000: 366-8). These disputes remained unresolved, and were to play out subsequently in other post-Rio forums. The South continued to push for financial support for tackling environmental problems, but it wanted that support delivered via official development assistance, while the North generally pushed for private sector activities, which were to its financial benefit (Humphreys 2006: 102-9). This conflict has become increasingly nuanced over the years, particularly within the Climate Change Convention, where it has become formalised - institutionalised even - by identifying countries as either 'Annex I parties' (developed) or 'non-Annex I parties' (developing) countries. This effectively entrenched the 'common but differentiated responsibilities' (CBDR) approach, which exacerbated tensions around finance, market mechanisms and political ideologies. However, this divide has become a significant point of contention for major players from the global North in the lead-up to UNFCCC negotiations in Paris 2015, for example. A primary argument used by the global North in opposition to the KP negotiations was related to concerns about the antiquated nature of these categories given current economic transformations (and environmental impacts, such as atmospheric pollution) in some countries identified as representing the global South. The North continues to push for market-based approaches as a method for combatting climate change, while the South largely objects to capitalist - and explicitly, neo-liberal - approaches to combatting environmental degradation (Abreu Mejía 2010).

UNCED has now receded into the past, along with the 2002 Johannesburg WSSD (or 'Rio +10') and the 2012 'Rio+20' (Rio de Janeiro). A number of developing countries, notably Brazil, Russia, India and China - the so-called 'BRICs' - have advanced economically, and their 
developed/developing status has become blurred. This has led to a fragmentation of the Southern 'bloc' in more recent times. Countries such as India are challenging previous geo-political and geo-economic perceptions, and are undergoing massive economic growth. Indeed, the North/ South divide has itself been challenged as a Northern construction that is hampering progress towards understanding environmental degradation and represents a de-territorialising transnational phenomenon (Doyle and Chaturvedi 2010: 516-17). However the 'convergence' model of North/ South relations should not be overstressed. Inequality is still an impediment to collaboration and necessitates structural and procedural changes to the way in which negotiations take place (Parks and Roberts 2008: 621 and 644).

As sustainable development has evolved, so too has non-state participation in its structures and processes. Two interesting developments happened as a consequence of UNCED. Business interests and private foundations provided support for the conference. Public interests, notably NGOs, were involved in lead-up discussions, and played a part in some of the preparatory committee work. There were also many non-state observers present at the Rio conference who were there with the express purpose of lobbying government delegations (Birnie 2000: 360-68). This had the effect of increasing their status in the eyes of some states, even if they could not participate formally in negotiations in the same way parties (member states of the UN who have ratified agreements) do. This influence has gone so far as to result in parties including text in negotiated agreements at the explicit request of - and, in some cases, even formulated by - NGOs. But it should be said that while NGOs can influence the texts that come out of intergovernmental sustainable development processes, such influence does not necessarily translate into actual impact (Humphreys 2004: 60). It should also be stressed that in such intergovernmental negotiations, the term 'NGOs' covers a wide range of actors, all with their own sub-acronyms, including business and industry NGOs (BINGOs), environmental NGOs (ENGOs), research and independent NGOs (RINGOs), youth NGOs (YOUNGOs), as well as women, farmers, labour, municipalities and so forth, depending on how various bodies under the UN system demarcate and categorise civil society participation. Within each sector or category, there are often significant divisions between those who have very different objectives fossil fuel industries versus the renewable energy sector within business, for example. It is also worth bearing in mind that non-state actors extend beyond these officially recognised NGOs to include civil society organisations (CSOs) and Indigenous peoples' organisations (IPOs), some of whom may be represented in the pre-determined UN-based categories for 
participation, and others who provide a broader base of stakeholder concerns for those who do engage under officially recognised categories. Even the definition of NGO in the UN system diverges with that adopted by the International Organization for Standardization (ISO): 'a non-profit association of citizens that operates independently of government or business structures and has non-commercial objectives related to environmental, consumer interest or sustainable development' (ISO TC 207 2003: 4).

But whatever the definition, the number of non-state actors has grown dramatically as a consequence of global environmental deliberations (Keck and Sikkink 1998: 10-12). This growth can be attributed to a change in economic influence from national to international venues of power, as well as on account of globalisation, the liberalisation of trade and the privatisation and deregulation agenda of many (most) governments themselves. All of these changes have increased the role of non-state sectors in the governance regimes that pertain to the political economy of sustainable development (Courville 2003: 271)

\section{Governance Quality of Sustainable Development}

With the rise of globalisation, and the shift away from government-led top down models, to governance involving multiple actors, several questions relating to the legitimacy of emerging institutional arrangements arise. Policies or programmes gain legitimacy on the basis of the validity of the structures and processes used to make them (input legitimacy), or if they deliver the goods (output legitimacy) - (Kersbergen and Waarden 2004: 156-8). On the input front, legitimacy has been linked to interest representation. It has been noted that 'regimes with a generally inclusive access and participation profile tend to be more effective than regimes with a more exclusive profile' (Wettestad 2001: 320). Regimes with limited participation seeking a 'quick fix' generally work well over the short term, but over the long term are less likely to have useful and positive outcomes, as stakeholders who may have either contributed to generating the problem and/or a solution to the problem have been excluded (Kölliker 2006: 208).

On a global level, the network-like nature of contemporary governance involves multiple actors, whose interactions can be more collaborative than traditional models (Haas 2004: 1). Environmental governance, understood as 'the coordination of interdependent social relations in the mitigation of environmental disruptions' represents one of the best examples of collaboration between civil society, private industry and the state (Mackendrick 2005: 22). Natural resource management specifically 
has been identified as one of the most useful focus areas to examine 'the increasing tendency for collaboration in many sectors where political and economic trade-offs also exist' (Overdevest 2004: 192).

Inclusiveness, equality and resources (also referred to as capabilities, or capacity-building in the literature), have been identified as the key elements of interest representation in global environmental governance (Cadman 2011: 17). Legitimacy is also closely linked to accountability and transparency (Bäckstrand 2006, Courville 2003). Accountability and transparency, interrelated concepts in much of the governance literature, have been connected under the broader rubric of organisational responsibility (Cadman 2011: 13-14). These can be seen as 'structural' components of participation in contemporary environmental governance.

Attention is also given to deliberation (decision-making) and implementation (Wettestad 2001). Collective decision-making has been identified as an important democratic component of legitimacy. Collective decision-making assists in the creation of agreements that result in collectively binding action (Scharpf 1997: 153). Although traditional approaches to making decisions such as voting are seen as more efficient, contemporary governance is showing an increasing preference for more discursive approaches such as consensus (Coglianese 2001, Dryzek 1994, Susskind 1994, Janicke 1992).

Where agreement cannot be reached, the presence of dispute settlement mechanisms is also identified as a critical aspect of decisionmaking, and one that is not generally well done in intergovernmental processes (Susskind 1994, Cadman 2011). Democracy, reaching agreement and settling disputes have all been linked to the notion of 'deliberation as process' in contemporary governance (Cadman 2011: 4).

Implementation is more related to output legitimacy, whereas interest representation and organisational responsibility as well as decisionmaking are more related to the processes of governance, and consequently more input-orientated. Focusing on the structural and procedural inputs of governance without focusing on the ensuing outputs can have a negative impact on efficiency (Smismans 2004: 459-60). Governance scholars also therefore pay attention to the idea that legitimacy is a product of the substantive outputs of the governance system and includes standards setting or the development of identifiable criteria. These outputs relate to the application and formulation of the governance system, and contribute to effectiveness on the basis of the quality of the outputs themselves (Kooiman 1993: 259-60). This is to be contrasted with the legitimacy derived from inputs, the implication being that success legitimates policies and related programmes: if the outputs do what they are supposed to, they are endowed with legitimacy by the 
general public - (Kersbergen and Waarden 2004: 156-8). However, there is a distinction to be made analytically between the outputs of a given policy programme and longer term outcomes. The implementation of agreements does not in itself guarantee success. Effectiveness is also related closely to behaviour change and problem-solving (Young 1999: 189). Durability, understood in terms of regime longevity, flexibility and adaptability is also essential (Wettestad 2001: 319, Cadman 2011: 15). These are the longer term outcomes required for success.

\section{Evaluating Governance Quality}

For the purposes of understanding the nature of the relationship between the various governance arrangements discussed above, a framework of principles, criteria and indicators $(\mathrm{PC} \& \mathrm{I})$ relating to governance quality is presented here (Lammerts van Beuren and Blom 1997: 5-9).

\section{Table 0.1 Principles, criteria and indicators for assessing governance quality}

\begin{tabular}{lll}
\hline Principle & Criterion & Indicator \\
\hline 'Meaningful & Interest representation & Inclusiveness \\
participation' & & Equality \\
& Organisational responsibility & Resources \\
& & Accountability \\
& Decision-making & Democracy \\
'Productive deliberation' & & Agreement \\
& & Dispute settlement \\
& Implementation & Behavioural change \\
& & Problem-solving \\
& & Durability \\
\hline
\end{tabular}

Source: Cadman 2009: 104.

In this study, two criteria (or categories) contribute to the principle (or value) of meaningful participation, interest representation and organisational responsibility. It refers to the structures of governance. In the discussion above regarding quality of governance, interest representation was connected to three governance components, which function as indicators (parameters for assessment): inclusiveness, demonstrating who 
participates in the system of governance; equality, indicating the calibre of relationship the participants enjoy; and resources, referring to the financial, technical and/or institutional capacities for a participant to ensure that their interests are represented in the system of governance. Two indicators make up the second criterion, organisational responsibility, and which are often closely interlinked: accountability, relating to the degree to which the actions of participants (usually delegated representatives of specific organisations) can be called to account by other actors, and the wider public; and transparency, which relates to the openness or visibility of participants' activities.

The two criteria of decision-making and implementation make up productive deliberation. This principle is concerned with the processes of governance. Three indicators are linked to decision-making: democracy, i.e. the extent to which actors can exercise democratic choice; agreement, concerning the manner in which that choice is exercised (voting, or consensus and so forth); and dispute settlement, relating to the ability to seek redress or take action if conflicts arise or if agreements cannot be reached. Implementation consists of three indicators: behaviour change, concerning the extent to which implementing agreements leads to changed behaviour regarding the problem in question; problem-solving, which relates to the extent to which the problem itself is actually resolved; and durability, encompassing the ideas of adaptability, flexibility and longevity.

\section{APPROACH AND METHODS OF EVALUATION}

Each case study was evaluated against these three parameters, using source materials, interviews with participants and surveys. Source documents included texts from the case studies themselves, literature from state and non-state actors, and commentaries provided by academic scholars and researchers. Interviews were also conducted with some of the participants directly involved in the mechanisms.

This qualitative interview-based research was undertaken in light of the fact that knowledge of the best practices and also major impediments to success in environmental policy instruments and market mechanisms are poorly understood. Additionally, participants in policy-making regimes and scholars alike argue that these instruments are complex, require specialist knowledge, and concern sensitive and often highly politicised issues of intergovernmental relations. Through the application of the method of open-ended interviewing (Ritchie and Lewis 2003), a range of 
perspectives was sought from key actors involved in international institutions in the biodiversity and climate change sectors. Questions were designed to elicit comments from interviewees on the need, effectiveness and potential for enhanced integration of governance, including of relevant policy instruments and market mechanisms. Data were collected through conducting interviews with senior, English-speaking government, intergovernmental, and non-governmental individuals whose work is associated with multilateral environmental agreements. Intergovernmental interviewees included those from UN agencies and treaty secretariats. Non-governmental interviewees were drawn from organisations actively involved in global scale negotiations of UN-based policy and multilateral environment agreements. Current or former ministers or senior officials were interviewed from each of three blocks of countries, namely the EU, JUSCANZ (other Western developed nations, originally comprised of Japan, the US, Canada, Australia and New Zealand as an intended counterbalance to the EU bloc). Now JUSCANZ is often referred to as 'the Umbrella Group', as several other countries, including Liechtenstein, Switzerland, Norway and, in some cases, Israel, have joined the group with the original founding members, and G77 (developing countries).

Thirty-five in-depth interviews were undertaken between May 2011 to May 2012, using confidential and semi-structured (open-ended) techniques (Minichiello et al. 1995). The range of views expressed by the interviewees on environmental policy instruments and market mechanisms are integrated into subsequent chapters where relevant. Quotes from the interviewees can be identified in the following text by citations containing a descriptor (intergovernmental organisation official, nongovernment organisation representative, European nation official, [other] developed nation official, or developing country representative) and an interviewee number. Quotes from respondents have been modified slightly for readability and coherence, yet with the intention of retaining the respondents' meanings. The observations from these interviewees are incorporated throughout the text where relevant, and are contained in the comparative analysis and recommendations.

In addition to the qualitative research conducted, primary source data for this book were gathered through an online survey that was developed and deployed in early 2015 to evaluate the governance quality of each of the mechanisms. This survey was based on the framework presented in Table 0.1. See Table 0.2. 


\section{Table 0.2 Summary of survey questions}

\begin{tabular}{|c|c|}
\hline Question & Indicator \\
\hline Do you think [the programme] is inclusive of your interests? & Inclusiveness \\
\hline Do you think [the programme] treats all interests equally? & Equality \\
\hline $\begin{array}{l}\text { What level of resources does [the programme] provide for you to } \\
\text { participate? }\end{array}$ & Resources \\
\hline Do you think [the programme] is accountable? & Accountability \\
\hline Do you think [the programme] is transparent? & Transparency \\
\hline Do you consider [the programme] acts in a democratic manner? & Democracy \\
\hline $\begin{array}{l}\text { Do you consider the making of agreements in [the programme] to be } \\
\text { effective? }\end{array}$ & Agreement \\
\hline $\begin{array}{l}\text { Do you consider the settling of disputes in [the programme] to be } \\
\text { effective? }\end{array}$ & $\begin{array}{l}\text { Dispute } \\
\text { settlement }\end{array}$ \\
\hline $\begin{array}{l}\text { Do you think [the programme] will contribute to changing the } \\
\text { behaviour it was created to address? }\end{array}$ & $\begin{array}{l}\text { Behavioural } \\
\text { change }\end{array}$ \\
\hline $\begin{array}{l}\text { Do you think [the programme] will help solve the problem it was } \\
\text { created to address? }\end{array}$ & Problem-solvin \\
\hline Do you consider [the programme] will be durable? & Durability \\
\hline
\end{tabular}

Note: Explanatory text and introductory materials omitted.

Survey participants were recruited through internet searches of publicly available email addresses of those involved in each of the programmes. Respondents were also invited to identify whether they came from the 'Global North/Developed Country' and 'Global South/Developing Country', and consisted of members of the biodiversity, forest and climate related policy communities. They were also asked to identify as 'Environmental', 'Social', 'Economic', 'Government', 'Academic' and 'Other'. Those who responded were invited to make substantive comments relevant to each indicator. Participants were asked to select and rate the programmes with which they had experience, and rated their perceptions of the governance quality of the various programmes by means of a five-point Likert scale, using the terms 'very low', 'low', 'medium', 'high' and 'very high'. The survey was confidential, and ran for four weeks in early 2015.

Survey respondents came from 60 countries. The majority of countries provided only one or two respondents, while the US had the largest number (nine), followed by India and Germany (six) Indonesia, Nepal and Malawi (four), and Canada, China, Malaysia, Spain and the UK (three). A total of 107 individuals responded, dispersed across the 
different mechanisms on the basis of their knowledge of the mechanism in question. The largest number of responses was for FSC (93) and the lowest for PES (81). A total of 47 respondents were from the North (developed countries) and 60 from the South (developing countries), with varying numbers selecting the specific mechanisms with which they were familiar. It should be noted that numbers of respondents varied across sectors. The largest sectors were environment (42) and academic (35). The smallest sectors were government (16), 'other' (6), social (5) and economic (3). In these latter four instances, there was a considerable 'outlier effect' whereby smaller numbers may have biased results, and the scores from these sectors should consequently be interpreted with some caution. Forty-six respondents from all sectors and regions provided specific comments. The results of the survey are contained in the following chapters.

\section{CHAPTER OUTLINES AND KEY FINDINGS}

Chapters 1-4 follow a similar format. A brief history and descriptive background introduces the relevant policy arena. This is followed by the case studies. A historical overview outlines the origins, development and controversies of the mechanism in question. This leads to a discussion of the sources and means of delivery of finance, which precedes an evaluation of North/South-state/non-state relations and an assessment of quality of governance, making use of the quantitative results and qualitative commentary contained in the online survey. A concluding section provides a brief analysis of the studies selected.

Chapter 1 focuses on the UNFCCC, the CDM and REDD+. Chapter 2 contains two case studies and two policy responses that arose, it could be argued, in the absence of a forest convention: forest certification, exemplified by the FSC and the PEFC. Chapter 3 investigates the EU trade-related initiative aimed at combatting illegal logging, FLEGT. This initiative is perhaps the 'odd person out' in the study, as it is less a sustainable development initiative and more of a regulatory mechanism that uses the market to combat illegal logging. There are, however, strong conceptual linkages between illegality and sustainability, and it is the synergies and tensions between these, that makes FLEGT an interesting policy instrument. Chapter 4 investigates the CBD and two associated policy instruments: PES and BOM. Chapter 5 provides a comparative analysis of the empirical data collected from both the online survey and interviews. The Conclusion provides an overview of environmental policy and policy instruments, and speculates on the future prospects of 
market-based mechanisms as a means of achieving sustainable development. The volume ends with a series of recommendations identified from the key informant interviews, along with the commentary provided by interviewees themselves.

\section{BIBLIOGRAPHY}

Abreu Mejía, D. 2010, 'The evolution of the climate change regime: Beyond a north-south divide?', International Catalan Institute for Peace, Working Paper, (2010/6).

Auty, R. 2002, Sustaining development in mineral economies: the resource curse thesis, London: Routledge.

Bäckstrand, K. 2006, 'Multi-stakeholder partnerships for sustainable development: Rethinking legitimacy, accountability and effectiveness', European Environment, 16 (5) 290-306.

Birnie, P. 2000, 'The UN and the environment', in Roberts, A. and Kingsbury, B. (eds) United Nations, Divided World: The UN's Roles in International Relations, Oxford: Oxford University Press.

Cadman, T. 2009, Quality, legitimacy and global governance: A comparative analysis of four forest institutions, $\mathrm{PhD}$ thesis, University of Tasmania.

Cadman, T. 2011, Quality and legitimacy of global governance: case lessons from forestry, Basingstoke, London: Palgrave Macmillan.

Coglianese, C. 2001, Is consensus an appropriate basis for regulatory policy? Cambridge, MA: Harvard University Press.

Courville, S. 2003, 'Social accountability audits: Challenging or defending democratic governance?', Law and Policy, 25 (3) 269-97.

Doyle, T. and Chaturvedi, S. 2010, 'Climate territories: A global soul for the global south?', Geopolitics, 15 (3) 516-35.

Dryzek, J. S. 1994, Discursive democracy: Politics, policy, and political science, Cambridge: Cambridge University Press.

Global Environment Facility 2010, The GEF incentive mechanism for forests a new REDD+ multilateral finance program. Viewed 7 April 2015, https:// www.thegef.org/gef/sites/thegef.org/files/publication/REDDEnglish.pdf.

Haas, P. M. 2004, 'Addressing the global governance deficit', Global Environmental Politics, 4 (4) 1-15.

Haigh, M. 2013, 'Stakeholders in climate policy instruments: What role for financial institutions?', in Climate Change and Global Policy Regimes: Towards Institutional Legitimacy, London: Palgrave Macmillan, 111.

Hindle, T. 2008, Guide to management ideas and gurus, Hoboken, NJ: John Wiley \& Sons.

Humphreys, D. 2004, 'Redefining the issues: NGO influence on international forest negotiations', Global Environmental Politics, 4 (2) 51-74.

Humphreys, D. 2006, Logjam: Deforestation and the crisis of global governance, London: Earthscan. 
IMF 2015, Factsheet: The IMF and the millennium development goals. Viewed 27 March 2015, http://www.imf.org/external/np/exr/facts/mdg.htm.

ISO TC 207 2003, 'Increasing the effectiveness of NGO participation in ISO TC 207', N590 Rev/ISO/TC NGO TG N28.

Jacobs, M. 2012, 'Green growth: Economic theory and political discourse', London, Inggris: Grantham Research Institute on Climate Change and the Environment, London School of Economics and Political Science (LSE). Viewed 15 April 2015, http://www.lse.ac.uk/GranthamInstitute/wp-content/ uploads/2012/10/WP92-green-growth-economic-theory-political-discourse.pdf.

Janicke, M. 1992, 'Conditions for environmental policy success: An international comparison', The Environmentalist, 12 47-58.

Jordan, A., Wurzel, R. K. W. and Zito, A. 2005, 'The rise of "New" policy instruments in comparative perspectives: Has governance eclipsed government?' Political Studies, 53 (3) 441-69.

Kazi, W. B. and Sarker, T. 2012, 'Fiscal sustainability and the natural resource curse in resource-rich african countries: A case study of Uganda', Bulletin for International Taxation, 66 (8) 1-12.

Keck, M. E. and Sikkink, K. 1998, Activists beyond borders: Advocacy networks in international politics, New York: Cornell University Press.

Kersbergen, K. v. and Waarden, F. v. 2004, "Governance” as a bridge between disciplines: Cross-disciplinary inspiration regarding shifts in governance and problems of governability, accountability and legitimacy', European Journal of Political Research, 43 (2) 143-71.

Kölliker, A. 2006, Conclusion 1: Governance and public goods theory, Basingstoke, London: Palgrave Macmillan.

Kooiman, J. 1993, Findings, speculations and recommendations in modern governance: New government society interactions, London: Sage.

Lammerts van Beuren, E. M. and Blom, E. M. 1997, Hierarchical framework for the formulation of sustainable forest management standards, Leiden: The Tropenbos Foundation.

Mackendrick, N. A. 2005, 'The role of the state in voluntary environmental reform: A case study of public land', Policy Sciences, 38 (1) 21-44.

Minichiello, V., Aroni, R., Timewell, E. and Alexander, L. 1995, In-depth interviewing: Principles, techniques, analysis, Sydney: Addison Wesley Longman.

Overdevest, C. 2004, 'Codes of conduct and standard setting in the forest sector constructing markets for democracy?' Relations Industrielles/Industrial Relations, 59 (1) 172-97.

Panayotou, T. 2013, Instruments of change: Motivating and financing sustainable development, London: Routledge.

Parks, B. C. and Roberts, J. T. 2008, 'Inequality and the global climate regime: breaking the north-south impasse', Cambridge Review of International Affairs, 21 (4) 621-48.

Pittock, J. 2013, Climate change and sustainable water management, in Cadman, T. (ed.) Climate change and global policy regimes: towards institutional legitimacy, London: Palgrave Macmillan.

Riddell, R. C. 2007, Does foreign aid really work? Oxford: Oxford University Press. 
Ritchie, J. and Lewis, J. 2003, Qualitative research practice, London: Sage Publications.

Sarker, T. 2013, 'Taxing for the future: an intergenerational perspective', The Asian Century, Sustainable Growth and Climate Change, Cheltenham: Edward Elgar, 85.

Scharpf, F. W. 1997, Games real actors play: Actor-centered institutionalism in policy research, Boulder, CO: Westview Press.

Smismans, S. 2004, Law, legitimacy, and European governance: Functional participation in social regulation, Oxford: Oxford University Press.

Stiglitz, J. E. 2003, 'Globalization and development', in Held, D. and KoenigArchibugi, M. (eds) Taming globalisation: Frontiers of governance, Cambridge: Polity Press.

Susskind, L. 1994, Environmental diplomacy: Negotiating more effective global agreements, New York, Oxford: Oxford University Press.

The World Bank 2011, 'Uganda country brief', Washington: World Bank.

UN 1987, Report of the World Commission on Environment and Development: Our common future, New York: United Nations Publications Department of Public Information. Viewed 15 July 2015, http://www.un-documents.net/wcedocf.htm.

UN 1993, Agenda 21: Programme of action for sustainable development, Rio declaration on environment and development, statement of forest principles, New York: United Nations Publications Department of Public Information.

Victor, D. G. and Keohane, R. O., 2010, The Regime Complex for Climate Change, Cambridge, MA: The Harvard Project on International Climate Agreements.

Wettestad, J. 2001, 'Designing effective environmental regimes: The conditional keys', Global Governance, 7 (3) 317-41.

Young, O. R. (ed.) 1999, Hitting the mark: Why are some environmental agreements more effective than others? Environment 20 189-91.

Zurn, M. and Koenig-Archibugi, M. 2006, 'Conclusion II: Modes and dynamics of global governance', in Koenig-Archibugi, M. and Zurn, M. (eds) New Modes of Governance in the International System: Exploring Publicness, Delegation and Inclusion, Basingstoke, London: Palgrave Macmillan. 